\title{
Om de uhellige mål og fordelingen af midler
}

\section{0 forskere fra 21 lande samledes ved den nordiske Bibliometri-workshop i Odense}

I 2008 udsendte Syddansk Universitets daværende rektor Jens Oddershede en e-mail med en opfordring til alle ansatte om at deltage i en såkaldt 'værdiproces'. Formålet med processen var at destillere tre nøglebegreber, der kunne afspejle organisationen. Efter mange møder blev der aftalt tre ord: Troværdig, Innovativ og Holistisk. Jens Oddershede fik de tre ord trykt på et krus, og alle ansatte fik det i gave.

De fleste af os lavede vittigheder om det og fandt at det var spild af tid og penge: Over frokostbordene diskuterede vi denne 'corporate style management' og dette tilsyneladende forsøg på at introducere de samme incitamentstrukturer, der fandtes i den private sektor. Vi - de ledelsesresistente forskere - troede, at vi vidste bedre. Vores arrogance i denne sag viser, hvor lidt vi forstod af krusets betydning.

'Værdikoppen' var et af de første håndgribelige beviser på, at New Public Management (NPM) var begyndt sin hærgen ved de danske universiteter. NPM bruges til at beskrive et sæt af reformer og styringsværktøjer, der skal øge effektiviteten i den offentlige sektor. Dens udgangspunkt er filosofien om 'managerialisme' og 'neoliberalisme'.
Konkurrence og omkostningseffektivitet er de styrende principper for allokering af ressourcer. Under NPM er allokeringen af ressourcer nemlig ikke orienteret efter principper som lighed og social retfærdighed, men i stedet kanaliseres ressourcer til de mest effektive enheder.

\section{Kun en tåbe frygter ikke h-indekset..}

Når allokeringen af ressourcer er orienteret mod de enheder, der er mest effektive, kommer der naturligvis ret stort fokus på at hitte ud af hvem, der er de mest produktive og at opstille mål herfor. Målene skal være enkle og gennemsigtige, så ledelsen kan begrunde ressourceallokering internt og bruge dem eksternt til at dokumentere over for skatteydere, medier og politikere, at 'produktionen' er effektiv.

Det var her, at bibliometrien for alvor fik luft under vingerne. Ganske kort tid før, i 2005, havde Jorge E. Hirsch foreslået det berømte og siden berygtede $\mathrm{h}$-indeks som en indikator for forskeres produktivitet og da det var let at regne ud og da data til dets beregning var lette at skaffe, blev h-indekset hurtigt meget populært. Det blev også indgående studeret og kritiseret og ud af kritikken voksede talrige andre mål for forskeres effektivitet.

I dag er bibliometri et vidt forgrenet forskningsfelt, der ifølge den danske wikipedia dækker "[...] brug af tal og statistik i forbindelse med forskning inden for især Biblioteks-og informationsvidenskab, videnskabsstudier og forskningsevaluering". Det er den pæne version. Den mindre pæne er, at det at bruge bibliometriske indikatorer til at udsige noget som helst om forskningskvalitet, endsige anvende det som nøgle til fordeling af ressourcer svarer til at skyde med spredehagl med bind for øjnene. Sagen er nemlig, at de data, som opgørelser af forskeres produktivitet bygger på, er hullede som en si.

SDU vært for international workshop Bibliometriens oprindelse, dens anvendelse og dens styrker og svagheder var emnet for den 26ende Nordiske bibliometri-workshop (NWB2021), som Syddansk Universitetsbibliotek havde æren af at være vært for fra 3-5. november. 120 forskere fra 21 forskellige lande havde tilmeldt sig og udover spændende oplæg fra tre keynote speakers, og 29 præsentationer bød 
